\title{
Research on the Cultural Integration Design of Ancestral Halls in Rural Public Space Based on the Revitalization of Rural Culture-A Case Study of Wuzhang Village, Chongren County, Jiangxi Province
}

\author{
Ting Zhang, Bowen Yin \\ Jiangxi Normal University, Nanchang 330022, Jiangxi Province, China
}

\begin{abstract}
Ancestral temple culture has a long history and is an important part of the traditional Culture of the Chinese nation. It carries the value orientation of economy and culture of a family and a period, and is the core cultural space of traditional villages. Its function renewal and activation utilization are the practical needs for the implementation of rural revitalization strategy and the protection and development of traditional villages. However, in the process of social development, folk ancestral temples, as ceremonial buildings, have been severely suppressed, resulting in the disappearance of many ancestral temples
\end{abstract}

Keywords: Ancestral Temple; Architecture; Local Culture; Innovation

\section{Aiming at the functional limitations of traditional public space in villages}

\subsection{Historical changes of village ancestral temple culture}

Wu get village is located in Fuzhou city of Jiangxi province in Chongren county hills photograph that mountain foothills, is two WuShui and get a water stream crossed. When the two rivers meet, they are called Xining Water (one of the tributaries of Chongren River). The villagers here live along the water and live in response to it. As an ancient village with a history of more than a thousand years, Wuzhang Village enjoys a high reputation in the country for its ancestral halls, which are famous for their cultural characteristics of combining Chinese and Western cultures. There were more than 70 ancestral temples in the ancient village during the Ming and Qing Dynasties. In addition to four main gates, there were many ancient buildings in the village: eight Jingbiao fang, 22 Wells, 6 Bridges, and 4 temples. At present, all the four main gates recorded in historical records have disappeared, and only 3 of the 22 ancient Wells are left. In addition to one in front of Gonggong Temple Hall, there is another one in Jiuqu Alley, which is called butterfly well by the villagers. Because several deep grooves have been ground in the mouth of the well, which looks like a butterfly, it is still in use at present, and has been changed into a mechanical well from a portable well. Among the more than 1,400 unincorporated villages in Chongyan, there are more ancestral halls in Wuzhang Village than any other one in China.

\section{Solutions to the functional limitations of traditional village public space}

\subsection{Functional transformation of rural ancestral temple public space}

Village ancestral temple has been not only a physical existence since its origin, but also a spiritual existence in local culture. With the change of history, the traditional function of ancestral temple as the carrier of clan culture is gradually weakened, while the new cultural connotation with the characteristics of The Times is constantly endogenous, which gradually gives rise to the era function of public cultural space of ancestral temple.

First, it develops into a public space for communication and entertainment. The long-term urban-rural dual system in history has resulted in relatively backward rural development, insufficient investment in rural public facilities and lack of public cultural space construction. In most villages, ancestral halls are the only public building space. At present, most rural ancestral halls have been expanded, renovated and reformed, and have the functions of cultural halls and venues for recreational and sports activities. According to local conditions, they have become "temple theater", farmhouse library, special exhibition hall, village meeting room, etc. Ancestral halls provide a reliable place for villagers. Villagers often carry out cultural activities in ancestral halls, making village ancestral halls an important front for prospering rural grass-roots culture and improving farmers' modern quality.

The second is to develop public space for administration. The function type of ancestral temple under this mode is mainly political function, which is a mode to continue and adapt to transform the original clan management function. For example, there

Copyright $(\mathrm{C}) 2020$ Ting Zhang et al.

doi: 10.18282/1-e.v9i3.1583

This is an open-access article distributed under the terms of the Creative Commons Attribution Non-Commercial License

(http://creativecommons.org/licenses/by-nc/4.0/), which permits unrestricted non-commercial use, distribution, and reproduction in any medium, provided the original work is properly cited. 
are three ancestral halls in Wuzhang Village. These three halls are large in scale, and some of them have large theatrical platforms inside. The three ancestral halls all face south and north. Chen's grand ancestral hall is well decorated. On the wall pillars on both sides of the gate, there are plastic pandragon patterns, especially the dragon body is inlaid with porcelain pieces. Although it is a rainy day, under the reflection of scattered light, just like pieces of dragon scales shine brightly. One of the ancestral halls can be used as the office space of the villagers' committee, subtly making use of the governance authority of the ancestral hall in the hearts of villagers, which essentially continues the original clan management function.

Third, it develops into a public space for cultural exhibition. The function types of ancestral halls under this mode are mainly cultural functions, which are suitable for well-preserved ancestral temple cultural relics with high historical and cultural value. Under the premise of strictly preserving their authenticity and integrity, they should be properly repaired, and cultural communication should be conducted through cultural publicity, folk performances and cultural relics exhibition.

\subsection{Design of village ancestral temple public space}

In view of the above functional transformation of public space, there are different designs respectively.

(1) The public space of entertainment communication pays more attention to the communication and leisure between people, and the space design layout is more relaxed and pleasant. Some ancestral halls with high degree of openness in Wuzhang Village can be designed.

(2) Because of the nature of its work, administrative management of public space requires more of a sense of solemnity. So the first choice of ancestral temple will be more prestigious ancestral temple. While carrying out the secondary design, the original appearance is retained as much as possible and the atmosphere of the ancestral hall itself is cleverly borrowed.

(3) The design of cultural exhibition space, and then retain the original appearance of the case, appropriate repair. Weixiang Gongci in Wuzhang Village has two floors with European-style Windows on the second floor. The gate of the first floor is lignous, but also protrusion showed the union of Chinese and Western civilization: that massiness fir wood gate, stone door frame and high threshold, door piers on both sides, it is the shikumen of popular Jiangnan. The reliefs of double phoenix sunrise and Kylin offering decorated in the lintels and doorposts are typical of traditional Chinese civilization. Above the lintel, in the middle of the geometric figure relief pattern, is the Western construction and decoration. The ancestral hall has well demonstrated the style and style of Wuzhang at that time and provided a good understanding of its history for future generations. Besides, it also USES its historical background and cultural background to design some stadiums and pavilions, which are venues for holding cultural activities, and pavilions to display historical relics of Wuzhang Village.

\section{Conclusion}

History has changed the people and things in the ancestral temple space. However, from the written materials such as ancestral temple buildings, inscriptions, genealogical trees, county Chronicles and oral historical memories left behind and rebuilt, it can be clearly seen that the ancestral temple in China has survived for a long time and is still playing various functions required for the religious space and place in the village after the development of The Times. History has changed the people and things in the ancestral temple space. However, from the written materials such as ancestral temple buildings, inscriptions, genealogical trees, county Chronicles and oral historical memories left behind and rebuilt, it can be clearly seen that the ancestral temple in China has survived for a long time and is still playing various functions required for the religious space and place in the village after the development of The Times.

\section{References}

1 Yang Guoan. Space and order: Villages, ancestral halls and family society in southeastern Hubei since Ming and Qing Dynasties [J]. Chinese Social and Histo rical Review, 2008, 9: 34-62.

2 Zhu Huayou, Chen Ningning. Village temple function evolution and its impact on the society of the new rural construction of the main-Based on Wenzhou Shencheng Town 50 shrine hall of overall research [J]. China Rural Observatory, 2009(2): 86-94.

3 Renovation and activation of Huizhou Traditional Village ancestral halls * Chen Xiaohua, Xie Wanzhen (School of Architecture and Planning, Anhui Jianzhu University; Anhui Urbanization Development Research Center, Hefei 230022, China).

$4 \mathrm{Wu}$ Leping, Zhang Xiaoping. Multi-dimensional Perspectives of "Cultural space" research at home and abroad [J]. Journal of Southwest University for Nationalities (Humanities and Social Sciences edition). 2016; 37(3): 7-12.

5 Chen Bo, Hou Xueyan. Public Cultural Space and Cultural Participation: An Empirical Study based on cultural Scene Theory [J]. Hunan Social Science, 20(2): 168-174.

6 Wang Shaofeng. Public Policy and Cultural Space [M]. Beijing: Xueyuan Press, 2007: 116.

7 Fei Xiaotong. Rural China [M]. Shanghai: Shanghai People's Publishing House, 2006.

$8 \mathrm{Fu}$ Caiwu, Hou Xueyan. Interpretation dimension and scene design of contemporary rural public cultural space in China. Hundred schools of art, 2016,32(6): 38, 43. 